\title{
POSTKOLONIALNA OBCOŚĆ W PRZEKŁADZIE NA JĘZYK „POZAKOLONIALNY"
}

\author{
JAKUB CZERNIK ${ }^{1}$ \\ (Uniwersytet Jagielloński, Kraków)
}

\begin{abstract}
Słowa kluczowe: postkolonializm, przekład, przekładoznawstwo, wyobcowanie, udomowienie, Chinua Achebe, Salman Rushdie

Key words: postcolonialism, translation, Translation Studies, foreignization, domestication, Chinua Achebe, Salman Rushdie
\end{abstract}

\begin{abstract}
Abstrakt: Jakub Czernik, POSTKOLONIALNA OBCOŚĆ W PRZEKŁADZIE NA JĘZYK „POZAKOLONIALNY”. „PORÓWNANIA” 20, 2017. T. XX, S. 107-124. ISSN 1733-165X. Przedmiotem niniejszego artykułu są mechanizmy towarzyszące przekładowi literatury postkolonialnej na język "pozakolonialny", czyli przeniesieniu tekstu poza języki i kultury uczestniczące w (post)kolonialnym zwarciu. Zagadnienia te są omówione na przykładzie przekładów na język polski powieści Chinuy Achebego Things Fall Apart oraz Salmana Rushdiego The Satanic Verses.
\end{abstract}

\begin{abstract}
Jakub Czernik, THE POSTCOLONIAL OTHERNESS TRANSLATED INTO A „NONCOLONIAL" LANGUAGE. "PORÓWNANIA" 20, 2017. VOL. XX, S. 107-124. ISSN 1733165X. This paper aims to describe the mechanisms of translating postcolonial literature into a "non-colonial" language, transmitting a text from languages and cultures which take part in a (post)colonial clash. These issues are illustrated with the examples taken from Polish translations of Chinua Achebe's Things Fall Apart and Salman Rushdie's The Satanic Verses.
\end{abstract}

Nie jest niczym odkrywczym stwierdzenie, że obcość kulturowa to problem podstawowy zarówno jeśli idzie o literaturę postkolonialną, jak i o przekład. Postkolonializm z różnicy kulturowej uczynił swój oręż w walce o określone cele kulturowe i polityczne, odwracając perspektywę wszechobecną w literaturze kolonialnej, traktującej to, co obce, jako gorsze, niższe i mniej wartościowe. Obcość jest też zagadnieniem kluczowym $\mathrm{w}$ rozumieniu przekładu i jest sensem jego istnienia, a wedle niektórych badaczy przekład istnieje nie tylko po to, by obcość niwelować, ale też umożliwia świadome doświadczanie tego, co obce/Obce (Berman 249).

1 E-mail: jakub.czernik@uj.edu.pl 
Znane propozycje Schleiermachera związane z przybliżaniem autora do czytelnika i odwrotnie współcześnie znalazły swoją kontynuację w proponowanej przez Lawrence'a Venutiego perspektywie analizowania przekładu, której skrajne punkty wyznaczają strategie określane przez tego badacza jako domestication i foreignization ${ }^{2}$ (Venuti 1995).

Różnica kulturowa aktywnie wpływająca na kształt tekstu, napięcie między dwiema kulturami i inne zbieżności dostrzeżone między literaturą postkolonialną a przekładem doprowadziły z czasem do traktowania obu tych zjawisk jako analogicznych względem siebie czy wręcz opartych na tych samych zasadach (Bassnett). Maria Tymoczko zauważa na przykład, że „literaturę postkolonialną można sobie wyobrazić jako rodzaj przekładu (traktowanego, rzecz jasna, ze znacznie większym namaszczeniem i pompą), w którym szacowne i święte szczątki (historyczne, mityczne i literackie) przenosi się z jednego uświęconego miejsca kultu w inne" (Tymoczko 430-431). W odniesieniu tak do przekładu, jak i postkolonializmu, zagadnienia te są, oczywiście, dobrze znane i szeroko omówione w literaturze przedmiotu, zwłaszcza przez naukowców reprezentujących obszary kulturowe uczestniczące w kolonialnym i postkolonialnym zwarciu (z Gayatri Spivak na czele). Niejednokrotnie też stawały się przedmiotem zainteresowania polskich badaczy zajmujących się postkolonializmem bądź przekładoznawstwem. Rzadsze natomiast, zwłaszcza w Polsce, są próby ukazania specyfiki przekładu w kontekście postkolonialnym ${ }^{3}$ (Bassnett, Trivedi). Wydaje się, że badacze nie doceniają skali przekształceń, jakim tekst postkolonialny ulega w przekładzie na język, który nie jest elementem toczącej się w tekście postkolonialnym walki między kulturami. Na potrzeby tego artykułu język tego rodzaju można nazwać mianem języka "pozakolonialnego”, a więc takiego, który nie uczestniczy w danej, konkretnej sytuacji kolonialnej (np. język polski, zewnętrzny w stosunku do napięcia sytuacji kolonialnej między kulturą brytyjską a kulturą ludów zamieszkujących terytorium obecnej Nigerii czy kulturą brytyjską a kulturą subkontynentu indyjskiego). Nie oznacza to, że taki język można postrzegać jako całkowicie pozbawiony zjawisk wynikających z kolonializmu - trudno sobie wyobrazić, by którykolwiek język europejski mógł zostać za taki uznany, a z pewnością nie można by tak myśleć o języku polskim.

Analiza różnych przykładów polskich tłumaczeń dzieł postkolonialnych sugeruje konieczność traktowania przekładów tego rodzaju tekstów jako zjawisk o własnej specyfice, nieco bliskiej tekstom traktowanym jako wielokulturowe i stąd

2 Ten pierwszy termin w polskiej literaturze przedmiotu oddawany jest konsekwentnie jako „udomowienie" (choć zdarzają się próby użycia terminu „domestykacja”). Ten drugi najczęściej oddawany jest jako „wyobcowanie”, rzadziej „forenizacja” (Bukowski i Heydel 24), choć niektórzy badacze proponują też termin "egzotyzacja”. Warto zauważyć, że w książce Venutiego foreignizing i exocitizing to dwie różne strategie, których nie można z sobą utożsamiać (Venuti 1995: 160).

3 Problematyce tej poświęcony został między innymi nr 33/2016 przekładoznawczego czasopisma „Przekładaniec". 
wymagającym szczególnego nastawienia ze strony tłumacza (Czuruta). Praca nad przekładami tekstów postkolonialnych, zbudowanych zawsze z kilku różnych idiomów kulturowych, funkcjonujących jako „labirynt luster, stawiający czytelnika i autora wobec ryzyka zagubienia się w niezliczonych, chaotycznych, niepotrzebnych odbiciach" (Tymoczko 430), domaga się odmiennego opisu od analizy przekładów tekstów „monokulturowych”, których punkty odniesienia osadzone są wyłącznie w jednej tradycji, jednej kulturze (rozumianej wąsko, w wymiarze narodowym lub etnicznym, bądź szerzej, w odniesieniu choćby do zachodniego kręgu kulturowego). Jak będę się starał wykazać, przekształcenia, jakim w przekładzie na język "pozakolonialny” ulega literatura postkolonialna, dotyczą samej jej istoty, zmieniają sensy i sposób jej odbioru o wiele bardziej niż w przypadku innego rodzaju tekstów literackich, a przez to uniemożliwiają ",taki sposób rozumienia obcego tekstu, jaki charakterystyczny był dla obcych czytelników" (Venuti 2009: 273). Stwierdzenie, że „,żadne tłumaczenie nie jest w stanie przekazać tekstu źródłowego w sposób wolny od zniekształceń" (Venuti 2013: 64), zyskało już dawno powszechną akceptację. Wydaje się jednak, że w przypadku przekładów literatury postkolonialnej zniekształcenia te mają charakter zasadniczy i dotykają sedna, samej istoty tekstów, o jakich tu mowa.

Weryfikując słuszność powyższego przekonania posłużę się polskimi tłumaczeniami dwóch powieści postkolonialnych. Pierwszą z nich jest Things Fall Apart nigeryjskiego pisarza Chinuy Achebe (Achebe 1994) z 1958 roku, uznawana przez niektórych za faktyczny początek funkcjonowania literatury postkolonialnej w obiegu globalnym (Kołodziejczyk 243). Pierwszy polski przekład tej powieści, autorstwa Małgorzaty Żbikowskiej, ukazał się w roku 1989 nakładem wydawnictwa Iskry pod tytułem Świat się rozpada (Żbikowska ${ }^{4}$ ); drugi przekład, autorstwa Jolanty Kozak, pod tytułem Wszystko rozpada się, w roku 2009 wydał Państwowy Instytut Wydawniczy (Kozak).

Drugim tekstem będzie powieść brytyjskiego autora wywodzącego się z subkontynentu indyjskiego (lub też indyjskiego autora związanego z Wielką Brytanią), Salmana Rushdiego, The Satanic Verses (Rushdie), której pierwsze wydanie ukazało się w Wielkiej Brytanii w roku 1988. Powieść ta reprezentuje zatem już inną epokę $\mathrm{w}$ rozwoju literatury postkolonialnej ${ }^{5}$. Także $\mathrm{w}$ tym przypadku dysponujemy dwoma przekładami na język polski i w obu przypadkach tłumacze zdecydowali się na tytuł Szatanskie wersety. Pierwszy wydany został bez podania informacji o nazwisku tłumacza, tłumaczki bądź tłumaczy i wydawnictwie (Szatańskie) w roku 1992, a więc w czasie, gdy negatywne konsekwencje publikacji tej powieści dotykały nie tylko samego autora, ale też jego tłumaczy i wydawców, a nawet księgarnie, w których

4 Z uwagi na specyfikę dalszej analizy i w celu uzyskania większej przejrzystości, odwołując się do tłumaczeń powieści Achebego i Rushdiego nie będę posługiwał się nazwiskami autorów, ale tłumaczy.

5 Zdaniem Doroty Kołodziejczyk, od lat osiemdziesiątych XX wieku można mówić o dojrzałej fazie rozwoju literatury postkolonialnej (Kołodziejczyk 248). 
książkę można było kupić. Drugi, autorstwa doświadczonego tłumacza literatury postkolonialnej, Jerzego Kozłowskiego (mającego na swoim koncie tłumaczenia tekstów Rushdiego, Zadie Smith, Kiran Desai, Elif Şafak czy Junota Díaza), ukazał się nakładem Domu Wydawniczego Rebis w dwudziestopięciolecie pierwszego wydania oryginalnego, w roku 2013 (Kozłowski).

Nie jest możliwe przeprowadzenie szczegółowej analizy obu tych powieści i wszystkich ich przekładów w niniejszym artykule i, choć zdecydowanie warta realizacji, nie jest ona moim celem. $Z$ konieczności zatem do analizy wybrano reprezentatywne przykłady, sygnalizujące strategie realizowane (nie zawsze konsekwentnie) przez autorki i autorów tłumaczeń, które można by umieścić na skali między udomowieniem a wyobcowaniem.

\section{Chinua Achebe, Things Fall Apart}

Akcja powieści afrykańskiego pisarza rozgrywa się w momencie zetknięcia się ludu Igbo zamieszkującego dorzecze dolnego Nigru z białymi (brytyjskimi) kolonizatorami. Kolonialna agresja doprowadza w powieści do podważenia podstaw miejscowej kultury i jej destrukcji za sprawą tak administracji, jak i misjonarzy chrześcijańskich przybyłych na te tereny wraz z nową władzą. Trzecioosobowy, wszechwiedzący narrator opowiada tę historię z punktu widzenia miejscowych, zarówno przyjmując ich perspektywę poznawczą, jak i zachowując pewne cechy języka i narracji (Appiah $\mathrm{x})$. Napisany w języku angielskim tekst utrzymany jest w konwencji realistycznej literatury anglojęzycznej (głównie brytyjskiej) ${ }^{6}$, znanej autorowi dzięki edukacji w kolonialnych szkołach, opartej zasadniczo na programie nauczania obowiązującym w metropolii, przy czym język narracji jest wyraźnie maksymalnie uproszczony. $\mathrm{Na}$ poziomie warsztatowym, "formalnym”, dominującym kodem kulturowym jest zatem kultura zachodnia, kolonialna (brytyjska), natomiast na poziomie treściowym, fabularnym, najważniejsze są czynniki związane z kulturą lokalną.

Autorki przekładów tej powieści na język polski poprawnie identyfikują tradycję powieściową, do której odwołuje się Achebe, i w tłumaczeniu starają się oddać charakterystyczny język narracji (przy czym zwłaszcza Jolancie Kozak zdarza się podwyższać rejestr wypowiedzi). Warto natomiast zwrócić uwagę na to, co w obu polskich przekładach dzieje się z kulturą Igbo, w oryginalnym tekście pełniącą funkcję elementu obcego, choć zrozumiałego dzięki odpowiednim zabiegom narracyjnym. Niejednokrotnie daje w tym przypadku o sobie znać niedostateczna

6 Problem ten był wielokrotnie poruszany przez badaczy twórczości Achebego; wielu z nich zauważało, iż nigeryjski autor nie tyle odtwarza i powtarza konwencje literatury realistycznej, co umiejętnie je wykorzystuje do własnych celów, dokonując ich rekonfiguracji; zob. Andrade; Quayson; Greenberg; Korang. Z uwagi na ograniczenia niniejszego artykułu, problem ten nie będzie przedmiotem dalszych rozważań. 
znajomość realiów kulturowych. Wyraźnie widać to w znajdującym się na jednej z pierwszych stron powieści fragmencie zapowiadającym i wyjaśniającym pewne elementy narracji:

Having spoken plainly so far, Okoye said the next half a dozen sentences in proverbs. Among the Ibo the art of conversation is regarded very highly, and proverbs are the palm-oil with which words are eaten (Achebe 4).

Następnych kilka zdań wypowiedział Okoye w formie przysłów. Ibowie przywiązują bowiem wielką wagę do sztuki konwersacji, a przysłowia są olejem palmowym, którym przyprawia się wypowiedź (Żbikowska 11).

Do tej chwili Okoye mówił prosto, lecz następnym kilku zdaniom nadał formę przysłów. Wśród Ibów bardzo wysoko ceni się sztukę konwersacji, a pr zy słow ia stan ow ią olej palmowy, z którym spożywa się słowa (Kozak 13).

Jak widać, Jolanta Kozak odtwarza oryginalną wypowiedź dość wiernie, choć nie unika podwyższenia jej rejestru (w jej tłumaczeniu słowa się „,spożywa", nie „,je" lub "zjada”, choć i w ten sposób można by przełożyć tę frazę). Żbikowska z kolei, tłumacząc afrykańskie powiedzenie, z jednej strony zdradza powierzchowną znajomość realiów kulturowych, traktując olej palmowy jako przyprawę, nie zaś zasadniczy składnik potraw, z drugiej zaś metaforyzuje wypowiedź.

Na nieco innego rodzaju problemy wskazuje przekład fragmentu opowiadającego o zasobach będących źródłem poważania, jakim wśród sąsiadów cieszy się Umuofia, miejsce zamieszkania głównego bohatera powieści. Wieś ta dysponuje nie tylko znaczącą siłą militarną, ale też środkami magicznymi, pomocnymi w przypadku rywalizacji z innymi miejscowościami. Środki te u Achebego określone są jako „war-medicine”, a wraz z rozwojem fabuły czytelnik dowiaduje się, że są to jakiegoś rodzaju przedmioty mające dysponować magiczną mocą. Żbikowska w tym przypadku zręcznie omija tę trudność - „war-medicine” to u niej „wojenne środki magiczne”, a "medicine men”, którzy mieli się nimi zajmować, stają się „,czarownikami". Z jednej strony mamy zatem do czynienia z próbą zachowania w przekładzie specyfiki kultury Igbo („wojenne środki magiczne”), z drugiej - z jej niwelowaniem („,czarowników" znamy z tekstów opisujących przedstawicieli licznych kultur). Kozak decyduje się na nieco inny zabieg - czarownicy pozostają, ale "war-medicine” stają się "czarami", których objaśnienie znajdziemy w przypisie podanym przez autorkę przekładu.

Umuofia was feared by all its neighbors. It was powerful in war and in magic, and its priests and medicine men were feared in all the surrounding country. Its most potent war-medicine was as old as the clan itself (Achebe 9). 
Umuofii bali się wszyscy sąsiedzi. Była groźnym przeciwnikiem, zarówno w walce jak i w magii. Miała najpotężniejszych kapłanów i czarowników. Posiadali oni najskuteczniejsze wojenne środki magiczne, które były tak stare, jak stary był sam klan (Żbikowska 14).

Umuofii bali się wszyscy sąsiedzi. Była potężna w wojnie i w czarach*, a jej kapłanów i czarowników lękał się cały okoliczny kraj. Najpotężniejszy wojenny czar Umuofii był tak stary, jak sam klan.

[przypis:] * Określenie „czar" używane w książce odnosi się do czegoś konkretnego, namacalnego - środka magicznego (proszku bądź kawałka materiału) (Kozak 17).

Ciekawsze - i zdecydowanie częściej w polskich tłumaczeniach widoczne wydają się natomiast zabiegi o charakterze udomawiającym, przybliżającym polskiemu czytelnikowi odległą kulturę za pomocą dopowiedzeń, racjonalizacji bądź zmiany pól semantycznych. Wiele tego rodzaju rozwiązań widać w opisie domostwa Okonkwo, głównego bohatera powieści.

Okonkwo's prosperity was visible in his household. He had a large compound enclosed byathick wall of red earth. His ow hut, or $o b i$, stood immediately behind the only gate in the red walls. Each of his three wives had her own hut, which together formed a half moon behind the $o b i$. The $\mathrm{b}$ a $\mathrm{r}$ was built against one end of the red walls, and long stacks of yam stood out prosperously in it. At the opposite end of the compound was a shed for the goats, and each wife built a small at tachment to her hut for the hens. Near the barnwasa small house, the 'medicine house' or shrine where Okonkwo kept the wooden symbols of his personal god and of his ancestral spirits. He worshipped them with sacrifices of kola nut, food and palm-wine, and offered prayers to them on behalf of himself, his three wives and eight children (Achebe 11).

Dostatek Okonkwa był widoczny w całym domostwie. Otaczał je gruby mur z czerwonej glinki.Obi - chata gospodarza - stała tuż zajedynym otworem wejściow y m. Chaty żon, ustawione tuż za obi, tworzyły półksiężyc. Z jednej strony muru była s z o p a , w której piętrzyły się stosy jamu, z drugiej z a g r o d a dla kóz. Każda z żon miała przy swojej chacie kurnik. Obok szopy stał mały domek, zwany przybytkiem fetyszy lub sanktuarium, w którym Okonkwo trzymał drewniane symbole osobistego boga i duchów przodków. Oddawał im cześć składając ofiary z orzecha kola, pożywienia i wina palmowego i modlił się d o nich w in ten cji swojej, swoich trzech żon i ośmiorga dzieci (Żbikowska 16-17).

Dobrobyt Okonkwo rzucał się w oczy w jego domostwie. Dużą zagrodę otaczał g r u b y mur z czerwonej ziemi.Osobista chata, czyli obi, Okonkwo stała 
tuż za j e d y n ą br a mą w czerwonym murze. Każda z trzech żon miała własną chatę, ustawioną wraz z pozostałymi w półksiężyc na tyłach o bi . Z jednej strony pod czerwonym murem znajdowała się s p i ż a r n i a , a w niej piętrzyły się dumnie podłużne stosy jamsów. Po przeciwległej stronie zagrody stała s z o p a dla kóz, a każda z żon d o b u dowała do swojej chaty nieduży kurnik. Obokstodoły wznosił się mały domek, "dom czarów”, czyli kaplica,w której Okonkwo trzymał drewniane symbole swoich osobistych bogów oraz duchów przodków. Czcił je ofiarami z orzechów kola, żywności i wina palmowego i wznosił do nich modły za siebie, swoje trzy żony i ośmioro dzieci (Kozak 19-20).

W tłumaczeniu Jolanty Kozak Okonkwo mieszka w będącej częścią dużego obejścia chacie otoczonej murem z ziemi, okalającym także spiżarnię, szopę dla kóz i kurniki. Budynek mieszczący przedmioty kultu jest tu „domkiem”, „domem czarów”, a wreszcie „kaplicą”, w której Okonkwo wznosi modły (określenia takiego raczej nie znajdziemy w etnologicznych opisach społeczności afrykańskich). U Żbikowskiej natomiast mur otaczający gospodarstwo Okonkwo zbudowany jest z czerwonej glinki, do wejścia nie prowadzi brama, lecz otwór wejściowy, na terenie domostwa znajdziemy szopę, zagrodę i kurnik, ale medicine house z tekstu oryginalnego tutaj staje się „małym domkiem, przybytkiem fetyszy lub sanktuarium”, w którym Okonkwo „modli się w intencji”. Tłumaczka odnosi się zatem do odmiennych pól semantycznych, z jednej strony dokonując daleko idącej stereotypizacji („otwór wejściowy” to o wiele mniej niż „brama”; jeśli dodać do tego fetysze, kojarzone z religiami określanymi mianem pierwotnych, to wyraźnie widać kształtowany tu obraz kultury prymitywnej), która mogłaby być odebrana już nie jako obcowanie, ale wręcz jako egzotyzacja, z drugiej zaś przenosi w sferę skojarzeniową bliską religii chrześcijańskiej określenia odnoszące się do kultu religijnego.

Przy okazji analizy tego fragmentu warto zwrócić uwagę na jeszcze jeden szczegół. Opisując gospodarstwo Okonkwo, Achebe używa pochodzącego z języka igbo słowa obi, od razu objaśniając jego znaczenie. W całym tekście słów zaczerpniętych z tego języka jest wiele, jednak co ciekawe, zazwyczaj nie są one objaśniane tak jak w tym przypadku. Autor zadbał jednak o to, by ich znaczenie stało się zrozumiałe dzięki lekturze kolejnych partii tekstu - dane słowo powtarza się w użyciu umożliwiającym jego zrozumienie lub przynajmniej osadzenie go w odpowiedniej przestrzeni semantycznej. W oryginalnym wydaniu zabiegowi temu towarzyszył krótki słowniczek umieszczony na końcu książki. Przykładem takiego postępowania mogą być nazwy lokalnych instrumentów, które pojawiają się po raz pierwszy na jednej z początkowych stron powieści bez żadnego wyjaśnienia. Z czasem sposób działania każdego z instrumentów i wydawany przez nie dźwięk zostaje objaśniony lub opisany. W przypadku gongu ogene dzieje się to już kilka ustępów dalej. Dzięki temu czytelnik, zetknięty początkowo z elementem obcym kulturowo, nazwanym w niekoniecznie znanym sobie języku, z czasem go przyswaja. 
He could hear in his mind's ear the blood-stirring and intricate rhythms of the ekwe and the $u d u$ and the ogene, and he could hear his own flute weaving in and out of them, decorating them with a colourful and plaintive tune (Achebe 4).

Okonkwo had just blown out the palm-oil lamp and stretched himself on his bamboo bed when he heard the ogene of the town crier piercing the still night air. Gome, gome, gome, gome, boomed the hollow metal. Then the crier gave his message, and at the end of it beat his instrument again (Achebe 7).

Jeśli przyjrzeć się obu polskim tłumaczeniom, okaże się, że ich autorki najwyraźniej uznają informacje zawarte $\mathrm{w}$ tekście oryginalnym za niewystarczające i decydują się na opatrzenie pojawiających się po raz pierwszy nazw krótkimi przypisami. Zastępują one hasła ze słowniczka z wydania oryginalnego i umożliwiają czytelnikowi polskiemu natychmiastowe zrozumienie opisywanych realiów kulturowych, ale należy też pamiętać, że przypisy tego rodzaju odwracają uwage czytelnika od tekstu głównego i niejednokrotnie bywają oceniane przez badaczy przekładów negatywnie jako elementy naddane, nieobecne w tekście oryginalnym.

Rozbrzmiały mu w uszach burzące krew w żyłach, splątane rytmy ekwe, udu i oge$n e^{* *}$. Posłyszał też to przypływające, to znów odpływające dźwięki swojego fletu. Dodawały rytmom barwnego, płaczliwego tonu, lecz efekt był żywy i wesoły.

[przypis:]

** Nazwy instrumentów muzycznych. Ekwe to drewniany bęben o głuchym brzmieniu, udu - drewniany bęben ze skórzaną membraną, ogene - metalowy gong (Żbikowska 10).

Okonkwo właśnie zdmuchnął lampkę oliwną i wyciągnął się na bambusowym łóżku, kiedy usłyszał ogene obwoływacza przeszywające ciszę nocną. Gome, gome, gome, gome, buczał wydrążony metal. Potem obwoływacz przekazał swoją wiadomość i ponownie uderzył w instrument (Żbikowska 12).

W wyobraźni już słyszał burzące krew, zawiłe rytmy ekwe**, udu*** i oge$n e^{* * *}$, słyszał własny flet wijący wśród bębnów swoją nutę, zdobiący miarowe dudnienie barwną, błagalną melodią.

[przypisy:]

** Ekwe - bęben drewniany.

*** Udu - odmiana bębna glinianego.

**** Ogene - rodzaj gongu (Kozak 12).

Okonkwo właśnie zdmuchnął lampę na olej palmowy i wyciągnął się na bambusowym łóżku, gdy usłyszał ogene obwoływacza, przeszywające dźwiękiem nocną ciszę. Gome, gome, gome, gome, bębnił pusty w środku metalowy krąg. Następnie ob- 
woływacz obwieścił wiadomość, po której z nów u d e rzył w s w ój instrument (Kozak 15).

Co zastanawiające, strategia polegająca na udomawianiu, dopowiadaniu i wyjaśnianiu treści kulturowych polskiemu czytelnikowi w przypadku obu przekładów nie jest realizowana konsekwentnie w całym polskim tekście. Podczas gdy w późniejszych partiach zarówno Żbikowska, jak i Kozak godzą się z zabiegiem autora, polegającym na objaśnianiu znaczenia poszczególnych słów z języka igbo za pomocą treści narracyjnej, nie definicji, pierwsze rozdziały pełne są przypisów od tłumaczek. Czasem są to jedynie krótkie objaśnienia, jak informacja na temat środka płatniczego, jakim posługuje się Okonkwo i inni bohaterzy powieści.

\section{[przypisy:]}

Kauri - muszelki używane w Czarnej Afryce jako płacidło (Żbikowska 8, przypis).

Kauri (cowrie) - muszelki (porcelanki) sprowadzane z Oceanu Indyjskiego, szeroko stosowane jako waluta w przedkolonialnej Afryce (Kozak 10, przypis).

Czasem jednak objaśnienia tego rodzaju przybierają rozmiary dużo większe, zwłaszcza w przypadku tłumaczenia Kozak. Dotyczy to opisu jamu czy też jamsu, rośliny będącej podstawą funkcjonowania społeczności Igbo i wyznacznikiem zamożności poszczególnych jej członków.

\section{[przypis:]}

Jam (pochrzyn, ignam) - pnąca bylina tropikalna, uprawiana ze względu na bulwy bogate w skrobię (Żbikowska 10).

Jams (pochrzyn, ignam) - roślina, której bogate w skrobię bulwy (jamsy) są w Afryce Zachodniej bardzo popularnym pożywieniem. Wyglądem przypominają bulwy ziemniaka czy czarnej rzepy, są jednak znacznie większe i cięższe (dochodzą nawet do 2 m długości i 18 kg wagi). Jams spożywany jest zazwyczaj w formie papki (fufu) otrzymanej przez ubicie w moździerzu ugotowanych bulw. W smaku przypomina ziemniaki (Kozak 12, przypis).

Jak widać, obie tłumaczki starają się nie tylko przetłumaczyć, ale też wytłumaczyć tekst powieści Things Fall Apart, dopowiadając informacje podane w tekście oryginalnym nie wprost lub wymagające uważnej lektury. Żbikowska wydaje się w tym względzie nieco mniej radykalna, natomiast przekład Kozak pełen jest objaśnień „dopisanych” do tekstu głównego i zawartych w przypisach 7 . Wybór takiej

7 Jej tłumaczenie opatrzone jest też zresztą obszernym aneksem, zawierającym informacje biograficzne na temat Achebego, krótki zarys jego twórczości i kulturoznawczo-etnologiczny esej na temat ludu Igbo. Jedyną pozatekstową informacją towarzyszącą tłumaczeniu Żbikowskiej, jeśli nie liczyć przypisów, jest krótka nota na temat pomocy, z jakiej tłumaczka korzystała przy opracowywaniu terminologii afrykańskiej. 
strategii jest o tyle zastanawiający, że w Things Fall Apart napięcie między kulturą ulegającą kolonizacji a kulturą kolonizującą zbudowane jest na dwa sposoby. Pierwszy z nich wykorzystuje, rzecz jasna, plan fabularny, zetknięcie dwóch kultur czyniąc jedną z głównych osi narracyjnych tekstu. Jednakże drugi sposób, który zdecydował o sukcesie powieści Achebego i miał stać się wzorem dla innych autorów postkolonialnych, polega na użyciu zasobów kulturowych kolonizatorów (język angielski, konwencja powieści realistycznej i dość skąpo tu obecne realia kultury europejskiej w wydaniu brytyjskim, pozbawione jakichkolwiek wyjaśnień lub dopowiedzeń ze strony narratora w rodzaju tych, które były przed chwilą przywoływane w kontekście kultury Igbo) i umiejętnym dołączeniu do nich elementów kultury skolonizowanych. Eliminacja czy próby łagodzenia tej obcości mogą ułatwiać zrozumienie tekstu, ale usuwają $\mathrm{z}$ niego napięcie tworzące się między tymi dwiema kulturami, przenikające nie tylko fabułę, ale i samą tkankę tekstu oryginalnego. Być może nagromadzenie elementów obcych kulturowo wydawało się przeszkadzać w odbiorze tekstu na tyle, że autorki przekładów postanowiły część z nich wyeliminować lub objaśnić, uznając, że w przeciwnym wypadku tekst stanie się po prostu niezrozumiały dla polskiego czytelnika. $Z$ drugiej strony należy zapytać, czy bez wyraźnie widocznej obecności elementów oznaczających kulturową odmienność polski czytelnik doceni tekst o stosunkowo nieskomplikowanej i do pewnego stopnia przewidywalnej fabule, napisany zgodnie z konwencjami literatury zachodniej i pod wieloma względami niewyróżniający się w dwudziestowiecznej produkcji powieściowej?

\section{Salman Rushdie, The Satanic Verses}

Napięcie między dwiema kulturami uczestniczącymi w kolonialnym zderzeniu, wykorzystane przez Achebe, w młodszej o 30 lat od Things Fall Apart powieści Salmana Rushdiego musiało przybrać odmienną postać. Autor wielokrotnie, zwłaszcza w okresie najgorętszych dyskusji o Szatańskich wersetach, podkreślał, że nie jest to powieść o islamie, ale o przychodzeniu na świat nowych bytów, nowych tożsamości, nowych rzeczywistości kulturowych. O ile Achebe w swojej książce opisywał moment pierwszego kontaktu kultury z czasem skolonizowanej z cywilizacją brytyjską, świat powieści Rushdiego to świat tożsamości mało stabilnych, zhybrydyzowanych. W jednym z komentarzy do Szatańskich wersetów Rushdie używa terminu mongrelized (od słowa mongrel - kundel), który w polskim tłumaczeniu został oddany jako „tożsamość mieszańca” (Rushdie 2013: 406). Trudno w tym przypadku mówić o jednej kulturze podlegającej kolonizacji i monolitycznej kulturze kolonizującej - w planie realistycznym powieści czytelnik napotyka bohaterów pochodzących z subkontynentu indyjskiego, ale władających różnymi językami, wyznających różne religie, przynależnych do rozmaitych klas społecznych, do tego 
przejawiających zróżnicowany stosunek do hegemonicznej kultury brytyjskiej. Ta z kolei także nie jest spójna - nawet stolica Wielkiej Brytanii przedstawiona jest w powieści jako świat białych Brytyjczyków, ale też imigrantów z różnych stron świata. Drugi wymiar powieści, wizje senne jednego z bohaterów, to z kolei swego rodzaju odbicie świata arabskiego $\mathrm{w}$ przełomowym momencie wykształcania się nowej rzeczywistości religijnej, politycznej i społecznej. Mnogość tożsamości, kultur i języków musi mieć wpływ na pracę, jaką do wykonania mają tłumacze tego tekstu.

Jednym z oczywistych problemów dla autorów polskich przekładów Szatańskich wersetów są odniesienia i nawiązania do kultur pozaeuropejskich, przyjmujące postać aluzji, przywołań postaci mitycznych i historycznych, kulinariów, realiów kulturowych i językowych. Już w pierwszych zdaniach powieści Rushdie ucieka się do zabiegu znanego nam z powieści Things Fall Apart i inkrustuje język angielski wyrażeniami pochodzącymi z hindi.

'To be born again,' sang Gibreel Farishta tumbling from the heavens, 'first you have to die. Ho ji! Ho ji! To land upon the bosomy earth, first one needs to fly. Tat-taa! Taka-thun! How to ever smile again, if first you won't cry? How to win the darling's love, mister, without a sigh? Baba, if you want to get born again...' (Rushdie 3).

Aby narodzić się ponownie - śpiewał Dżibril Fariszta, spadając z niebios - najpierw musisz umrzeć. Ho dżi! Ho dżi! Aby bezpiecznie wylądować na Matce Ziemi, trzeba najpierw latać. Tat-taa! Taka-thun! Jak może w ogóle na twojej twarzy pojawić się uśmiech, jeżeli wcześniej nie zapłaczesz? Hej, panie szanowny, jak chcesz pan zdobyć miłość ukochanej bez jednego westchnienia? Baba, jeżeli chcesz narodzić się ponownie... (Szatańskie 11).

Aby się znów urodzić - śpiewał Dżibril Fariśta, spadając z niebios - umrzeć najpierw trzeba. Ho dźi! Ho dźi! Aby na ziemi osiąść, wzleć najpierw do nieba. Tat-taa! Taka-than! Nie ma uśmiechu bez łez ronienia. By serce zdobyć, trzeba westchnienia. Baba, aby się znów urodzić... (Kozłowski 11).

Jak widać, w tym przypadku polscy tłumacze nie redukują efektu obcości, jakkolwiek zostaje ona nieco oswojona za pomocą glosariusza znajdującego się na końcu książki (co ciekawe, wyjaśniającego poszczególne terminy na bardzo różne sposoby).

ta k a - th a n - (hindi/urdu) przykład sekwencji sylab używanej w klasycznej muzyce indyjskiej, m.in. do zapamiętania rytmu (Kozłowski 604).

ho dźi - (hindi/urdu) wykrzyknik, znaczy: hej ho!, hej tam! (Kozłowski 595). 
Ho dżi! ho d żi! - (hind.) dżi - odpowiednik polskiego „pan, pani, państwo”; dodawany jest do nazwisk, terminów pokrewieństwa i słów oznaczających osoby spełniające istotne i obdarzone szacunkiem role i zawody. Tu w znaczeniu: „oho, szanowny panie / szanowni państwo, oho!" (Szatańskie 578).

Oprócz przykładów wyobcowywania można dopatrzyć się jednak także nielicznych świadectw innego rodzaju decyzji podjętych przez tłumaczy. Jest tak choćby ze słowem „namaqool”, oznaczającym coś/kogoś nielogicznego, absurdalnego, głupiego, które skierowane jest do jednej ze spadających z nieba postaci:

I am strictly for your eyes only, maybe you are going crazy, what do you think, you namaqool, you piece of pig excrement, my love (Rushdie 7).

Ukazuję się wyłącznie twoim oczom, może zaczynasz wariować, jak myślisz, ty namaqool, ty kawałku świńskiego łajna, mój ty kochany (Szatańskie 16-17).

Widzą mnie tylko twoje oczy, może popadasz w szaleństwo, co ty sobie myślisz, ty namakulu, ty kawałku świńskiego gówna, ukochany mój (Kozłowski 16).

Autor przekładu wydanego w roku 1992 zdecydował się na pozostawienie w niezmienionej formie wyrazu obecnego w oryginale (bez podania jakiegokolwiek tłumaczenia), Kozłowski natomiast dokonuje ciekawego przekształcenia - spolszczając to słowo, rezygnuje z zachowania bądź próby zrekonstruowania jego oryginalnego znaczenia za pomocą odpowiednich ekwiwalentów, tworzy neologizm semantycznie pusty, licząc na to, że korzystając z kontekstu, polski czytelnik potraktuje to słowo jako obelgę, zgodnie z funkcją, jaką pełni ono w oryginale. Obcość kulturowa, obecna w tym miejscu w tekście oryginalnym dzięki słowu zaczerpniętemu z języka hindi, w tym przekładzie zostaje zredukowana, a na jej miejsce pojawia się konfundujący termin pozbawiony jakichkolwiek odniesień kulturowych czy językowych, który jednakże z powodzeniem może pełnić funkcje odpowiadające jego roli w tekście oryginalnym.

Na kulturze subalternów autorzy polskich tłumaczeń dokonują operacji dość przewidywalnych, natomiast szczególnie interesujące jest to, co dzieje się w przekładach z kulturą brytyjską, teoretycznie polskiemu czytelnikowi o wiele bliższą, bardziej zrozumiałą, która nie powinna sprawiać większych problemów w odbiorze. Tymczasem nawet dla czytelnika dobrze się w niej poruszającego w lekturze polskich przekładów Szatańskich wersetów staje się ona trudno rozpoznawalna lub wręcz niemożliwa do zdekodowania. Jedynie niektóre cytaty, zapożyczenia i nawiązania intertekstualne opisane są w tekście oryginalnym na tyle wyraźnie, że trudno byłoby o pomyłkę w ich zidentyfikowaniu. Dalszy ciąg wspomnianej przed chwilą pieśni śpiewanej przez Dżibrila Farisztę: 
'I tell you, you must die, I tell you, I tell you' (Rushdie 3).

Mówię ci, musisz umrzeć, mówię ci, mówię (Szatańskie 11).

Ja ci mówię, umrzeć trzeba, mówię ci, mówię (Kozłowski 11).

odbiorca tekstu oryginalnego rozpozna jako cytat z Alabama Song śpiewanej przez Kurta Weilla, The Doors i Davida Bowie. Ten sam fragment przetłumaczony na język polski raczej nie odnosi do żadnych znanych treści przede wszystkim dlatego, że teksty piosenek rockowych rzadko funkcjonują w przekładach, a jeśli nawet to się zdarza, to przekłady te nieczęsto pełnią funkcję przekładów kanonicznych, które byłyby rozpoznawalne dla każdego.

Tego rodzaju problemów z kulturą anglosaską pojawia się w polskich przekładach Szatańskich wersetów wiele. Do szczególnie ciekawych przykładów należy dalszy ciąg pierwszej sceny powieści, w której spadający z nieba Saladyn Ćamća, próbując przeciwstawić się pieśni wznoszonej przez Dżibrila Fariśtę ${ }^{8}$, sięga po tekst Rule, Britannia!, jednej z najbardziej rozpoznawalnych brytyjskich pieśni patriotycznych (Markiewka 147-148).

What Farishta heard wafting across the improbable night sky was an old song, too, lyrics by Mr James Thomson, seventeen-hundred to seventeen-forty-eight. ' ... at Heaven's command,' Chamcha carolled through lips turned jingoistically redwhiteblue by the cold, 'arooooose from the aaaazure main.' Farishta, horrified, sang louder and louder of Japanese shoes, Russian hats, inviolately subcontinental hearts, but could not still Saladin's wild recital: 'And guardian aaaaangels sung the strain' (Rushdie 6).

I oto Fariszta usłyszał, jak przez nieprawdopodobne nocne niebo płynie stara piosenka, wiersz Jamesa Thomsona od wersu tysiąc siedemset do tysiąc siedemset czterdzieści osiem. - ...z polecenia Niebios - popłynęły radosne wersety z ust Czamczy, którego wargi przybrały z zimna szowinistyczny, czerwono-biało-niebieski kolor, - heeen-tam, z lazuroweeego powstał oceanu. - Przerażony Fariszta śpiewał coraz głośniej o japońskich bucikach, rosyjskich czapkach, niezmiennie czystych subkontynentalnych sercach, lecz wciąż nie mógł uciszyć gwałtownej recytacji Saladyna: - A aniołooowie stróóóże śpiewali radośnie (Szatańskie 14).

8 Ten pieśniowy dwugłos wpleciony jest w starannie zbudowaną opozycję między rozchwianą tożsamością hybrydową subalterna uznającego swoją pozycję i postkolonialną kondycję, przyznającego, że jest zlepkiem różnych tożsamości i kultur (piosenka powtórzona z Dzieci pótnocy), a charakteryzującego się nie mniej hybrydyczną tożsamością subalterna stosującego postkolonialną mimikrę (słowo to, użyte jako termin spopularyzowany w badaniach postkolonialnych przez Homiego Bhabhę, pada zresztą w tym fragmencie: „his pathetic personality, that half-reconstructed affair of mimicry and voices"; Rushdie 9), próbującego zachowywać się w każdym calu niczym angielski dżentelmen, przyodziany w zapiętą na odpowiednie guziki marynarkę i z melonikiem na głowie. 
I tym, co usłyszał Fariśta, była również stara pieśń rozchodząca się po tym niezwykłym nocnym niebie, słowa pana Jamesa Thomsona, tysiąc siedemset-tysiąc siedemset czterdzieści osiem.

- ... na rozkaz niebios - z nacjonalistycznie czerwonobiałosinych z zimna ust Ćamci dobywał się radosny śpiew - wzniooooosła się z lazuuuuuru morza.

Przerażony Fariśta śpiewał coraz głośniej o japońskich butach, rosyjskich uszankach, niewzruszenie subkontynentalnych sercach, nie zdołał jednak uciszyć dzikiego recitalu Saladyna:

- Anielski śpieeeeew zabrzmiał w przestworzach (Kozłowski 14).

Cytaty rozpoznawalne dla każdego Brytyjczyka (a także dla wielu mieszkańców terenów skolonizowanych przez Brytyjczyków), ponownie, jak w przypadku wcześniejszego przykładu, dla polskiego czytelnika tłumaczenia nie są rozpoznawalne. W przekładzie dochodzi zatem do wyobcowania elementu, który dla odbiorcy tekstu oryginalnego nie miał być czymś nieznanym, pozbawionym odniesień. Sprawę może nieco ułatwiać wskazówka zawarta w tym fragmencie przez autora, a mianowicie nazwisko autora pieśni (Jamesa Thomsona) wraz z towarzyszącymi temu nazwisku liczbami. O ile Kozłowski nie stara się w żaden sposób owych liczb (oznaczających daty życia Thomsona) dopowiadać, o tyle tłumaczenie z roku 1992 zawiera błąd, dość zabawny, acz doskonale ilustrujący skalę trudności, jaką kultura brytyjska przepuszczona przez postkolonialne sito może sprawiać po przeniesieniu poza pierwotny kontekst - tu daty życia Thomsona potraktowane są jako numery wersów w tekście jego autorstwa.

Skoro tak trudne okazują się odwołania do kultury wysokiej, do tekstów o randze kanonicznej i klasycznej, nic dziwnego, że problematyczne stają się elementy o randze niższej, związane z popkulturą czy slangiem, jak poniższa uwaga dotycząca Dżibrila Fariśty:

He travelled alone, shunning the company of the other members of the Prospero Players troupe, who had scattered around the economy class cabin wearing Fancy-a-Donald T-shirts and trying to wiggle their necks in the manner of natyam dancers (Rushdie 74).

Podróżował sam, stroniąc od towarzystwa pozostałych członków trupy Prospero Players, którzy siedzieli w różnych miejscach kabiny turystycznej, wszyscy ubrani w koszulki z Kaczorem Donaldem, i próbowali wykręcać szyje jak tancerki natyam (Szatańskie 86).

Podróżował sam, stroniąc od towarzystwa rozproszonych po klasie ekonomicznej w koszulkach z napisem „Fancy a Donald?" pozostałych członków grupy Prospero Players, którzy próbowali kręcić szyjami jak tancerze natjam (Kozłowski 87).

Autor przekładu z 1992 roku zakłada, że Donald ze wspomnianych koszulek to Kaczor Donald (Donald Duck) z kreskówek Walta Disneya. Kozłowski, mający na 
początku XXI wieku lepszą niż w latach dziewięćdziesiątych poprzedniego stulecia możliwość zidentyfikowania właściwego punktu odniesienia (m.in. dzięki bardzo szczegółowemu zestawieniu dostępnemu w internecie - zob. Brians) w swoim tłumaczeniu pozostawia frazę Fancy a Donald i dodaje przypis:

Napis należy odczytać jako Fancy a fuck? (Chcesz się bzykać?), ponieważ „Donald” występuje w połączeniu z „Duck” (Kaczor Donald), a "duck” rymuje się z "fuck” - tego typu igraszki słowne są jedną z cech londyńskiego dialektu cockney (Kozłowski 583, przypis 3$)$.

Podane powyżej przykłady to tylko niewielki wyimek z ogromnego zasobu świadczącego o tym, że także w przypadku polskich przekładów Szatańskich wersetów doszło do pewnego zaburzenia opozycji i napięć kulturowych, będących istotą tej powieści i istotą literatury postkolonialnej w ogóle. W tekście oryginalnym kultura brytyjska jest tym elementem, który pełni rolę kultury hegemonicznej, rozpoznawalnej i znanej czytelnikowi. Ma być ona niejako znajomym podłożem, na które przeszczepiane są elementy kulturowo obce, zaczerpnięte z subkontynentu indyjskiego. W przekładzie na język polski to właśnie kultura obca (kultury obce) względem podstawowego środowiska, $w$ jakim osadzona jest narracja, paradoksalnie może stać się łatwiejsza do rozpoznania i zidentyfikowania, choćby dzięki zamieszczonemu w książce glosariuszowi. Kultura brytyjska natomiast, pozbawiona takich pozatekstowych narzędzi pomocniczych, może stać się słabo rozpoznawalna. Nawiązania do niej, nieoznaczone kursywą, niepozostawione w języku oryginalnym, mogą łatwo umknąć uwadze nawet dobrze zorientowanemu i oczytanemu czytelnikowi. Co ważne, nie dochodzi tu jednak do konsekwentnej zamiany miejsc i z tego powodu nie mamy do czynienia z zastąpieniem oryginalnego "spięcia” kulturowego jego przeciwieństwem, ale z zaburzeniem i nieuniknionym osłabieniem zbudowanego przez Rushdiego kontrastu między metropolią i kolonią, tym, co znane, i tym, co obce.

\section{Konkluzje}

Choć na podstawie kilku wybranych fragmentów dwóch odległych od siebie czasowo powieści postkolonialnych trudno wyprowadzać uniwersalne wnioski, widać wyraźnie, jakim przekształceniom ulegają w polskim przekładzie mechanizmy stanowiące sedno literatury postkolonialnej. Elementy pierwotnie obce, zakłócające język dominujący i pełniący funkcję podstawowego, nie-obcego $\mathrm{w}$ danym tekście, w przekładzie na język umiejscowiony poza opozycją subalterna - hegemona, kultury podporządkowanej i podporządkowującej, peryferii i metropolii, pozostają zazwyczaj obce, choć tłumacze dokonują na nich rozmaitych zabiegów, czasem przechylając się na stronę udomowienia i ową obcość redukując, czasem 
wręcz ją uwydatniając, pozostawiając w pozycji obcości radykalnej. Obierane strategie translatorskie nie pozostają bez wpływu na esencjalne dla tekstów postkolonialnych napięcie między elementami kultury podporządkow(yw)anej i kultury hegemonicznej, zaburzając, a niekiedy niwelując stwarzany przez autorów kontrast między nimi.

Ciekawe jest także to, co dzieje się z kulturą pełniącą w tekście oryginału funkcję nie-obcej, zrozumiałej dla pierwotnego czytelnika docelowego, stanowiącej dlań co najmniej istotny punkt odniesienia. Zmagania tłumaczy z tekstem Rushdiego pokazują, jak dalece obce stają się nawet podstawy zasobu kulturowego, wykorzystanego przez autora. Pierwotna opozycja "obce - nie-obce” w przekładzie zmienia się w stosunek "obce - obce” za sprawą trzeciego czynnika - języka przekładu, nieuwzględnionego w oryginalnej strukturze tekstu, na wstępie i w tytule tego artykułu określonego mianem "pozakolonialnego".

Jaką funkcję może pełnić ten nowy czynnik? Czy - korzystając z przywoływanej przez Jarniewicza Ricoeurowskiej metafory - miałby stać się elementem gościnnym? A może - odwołując się do słów Frosta wykorzystanych przez Barańczaka - pomagałby ocalać w tłumaczeniu to, co w innym wypadku nieuchronnie w nim ginie? Czy może, jeśli za Edwardem Balcerzanem potraktujemy tłumaczenie jako „wojnę światów”, przekład literatury postkolonialnej na język pozakolonialny mógłby tu pełnić funkcję mediatora? Przeprowadzona powyżej analiza zdaje się przeczyć tego rodzaju optymistycznym konkluzjom. Przekierowanie tekstu postkolonialnego poza jego oryginalne konteksty staje się raczej zakłóceniem niż wzmocnieniem wysyłanego przezeń sygnału. Można by zaryzykować stwierdzenie, że przekład literatury postkolonialnej na język „pozakolonialny” raczej nie tłumaczy, a tłumi kontrast kulturowy, który jest sensem, sednem i znakiem rozpoznawczym tej grupy mocno przecież zróżnicowanych tekstów; zamiast przekazywać znaczenia, przyczynia się do ich utraty, której może towarzyszyć tworzenie się znaczeń nowych. Taka perspektywa zbliżałaby przekłady literatury postkolonialnej do takiego rozumienia, jakie sugeruje Theo Hermans, mówiący o tłumaczeniu jako o nowym tekście „wyłaniającym się obok wcześniej istniejącego i dopiero wtedy przemieniającym się i rozpoznawanym jako tłumaczenie tekstu pierwotnego" (Hermans 111).

\section{BIBLIOGRAFIA}

Achebe, Chinua. Things Fall Apart. New York - London - Toronto: Alfred A. Knopf, 1994.

Andrade, Suzan Z. "The Problem of Realism and African Fiction". NOVEL: A Forum on Fiction 42 nr 2 (2009). S. 183-189.

Appiah, Kwame Anthony. "Introduction". Achebe, Chinua. Things Fall Apart. New York - London Toronto: Alfred A. Knopf, 1994. 
Bassnett, Susan. "Postcolonialism And/as Translation". The Oxford Handbook of Postcolonial Studies. Red. G. Huggan. Oxford: Oxford University Press, 2013.

Bassnett Susan, Trivedi Harish, red. Post-Colonial Translation. Theory and Practice. London - New York: Routledge, 1999.

Berman, Antoine. „Przekład jako doświadczenie Obcego”. Przeł. Uta Hrehorowicz. Wspótczesne teorie przekładu. Antologia. Red. P. Bukowski, M. Heydel. Kraków: Wydawnictwo Znak, 2009. S. 249-264.

Brians, Paul. “Notes on Salman Rushdie The Satanic Verses (1988)". Web. 15.12.2016. <http:// public. wsu.edu/ brians/anglophone/satanic_verses/>

Bukowski Piotr, Heydel Magda. „Przekład - język - literatura”. Wspótczesne teorie przekładu. Antologia. Red. P. Bukowski, M. Heydel. Kraków: Wydawnictwo Znak, 2009. S. 5-37.

Czuruta, Olga. „Przekład tekstu wielokulturowego albo polilog międzykulturowy”. Przekład - Jezzyk - Kultura IV. Red. R. R. Lewicki. Lublin: Wydawnictwo Uniwersytetu Marii Curie-Skłodowskiej, 2015. S. 85-96.

Greenberg, Jonathan. „Okonkwo and the Storyteller: Death, Accident, and Meaning in Chinua Achebe and Walter Benjamin". Contemporary Literature 48 nr 3 (2007). S. 423-450.

Hermans, Theo. Narada jezzyków. Red. M. Heydel, K. Szymańska. Przeł. Agnieszka Dauksza et al. Kraków: Wydawnictwo Uniwersytetu Jagiellońskiego, 2015.

Kołodziejczyk, Dorota. „Postkolonialny zamach stanu w literaturze”. Literatura na Świecie 1-2 (2008). S. 241-257.

Korang, Kwaku Larbi. „Making a Post-Eurocentric Humanity: Tragedy, Realism, and Things Fall Apart”. Research in African Literatures 42 nr 2 (2011). S. 1-29.

Kozak, Jolanta (przeł.). Chinua, Achebe. Wszystko rozpada się. Warszawa: Państwowy Instytut Wydawniczy, 2009.

Kozłowski, Jerzy (przeł.). Salman, Rushdie. Szatańskie wersety. Poznań: Dom Wydawniczy Rebis, 2013.

Markiewka, Tomasz. „Między wersetami. Przekład prozy Salmana Rushdiego w kontekście postkolonialnej teorii translacji". Przekładaniec 27 (2013). S. 131-151.

Quayson, Ato. "Realism, Criticism, and the Disguises of Both: A Reading of Chinua Achebe's Things Fall Apart with an Evaluation of the Criticism Relating to It". Research in African Literatures $25 \mathrm{nr} 4$ (1994). S. 117-136.

Rushdie, Salman. The Satanic Verses. London: Vintage Books, 2006.

Rushdie, Salman. „W dobrej wierze”. Przeł. Ewa i Tomasz Hornowscy. Rushdie, Salman. Ojczyzny wyobrażone. Eseje i teksty krytyczne 1981-1991. Poznań: Dom Wydawniczy Rebis, 2013. S. 405-425.

Szatańskie wersety. Salman Rushdie. (brak nazwiska tłumacza, brak miejsca wydania), 1992.

Tymoczko, Maria. „Literatura postkolonialna i przekład literacki”. Przeł. Agata Sadza. Wspótczesne teorie przekładu. Antologia. Red. P. Bukowski, M. Heydel. Kraków: Wydawnictwo Znak, 2009. S. 430-447.

Venuti, Lawrence. „Przekład, wspólnota, utopia”. Przeł. Magdalena Heydel. Wspótczesne teorie przekładu. Antologia. Red. P. Bukowski, M. Heydel. Kraków: Wydawnictwo Znak, 2009. S. 267-293.

Venuti, Lawrence. The Translator's Invisibility. A History of Translation. New York: Routledge, 1995.

Venuti, Lawrence. Translation Changes Everything. Theory and Practice. London - New York: Routledge, 2013.

Żbikowska, Małgorzata (przeł.). Chinua, Achebe. Świat się rozpada. Warszawa: Iskry, 1989. 